\title{
Tanja Gradečak
}

Filozofski fakultet Sveučilišta Josipa Jurja Strossmayera u Osijeku

Lorenza Jägera 9, HR-31000 Osijek

tgradeca@ffos.hr

\section{Barbara Kružić}

Filozofski fakultet Sveučilišta Josipa Jurja Strossmayera u Osijeku

Lorenza Jägera 9, HR-31000 Osijek

barbara.kruzic88@gmail.com

\author{
Alma Vančura \\ Filozofski fakultet Sveučilišta Josipa Jurja Strossmayera u Osijeku \\ Lorenza Jägera 9, HR-31000 Osijek \\ avancura@ffos.hr
}

\section{APOFASTIČKE KONSTRUKCIJE U HRVATSKOM JEZIKU NA RAZMEĐU RETORIKE I SINTAKSE}

Analizom mnogih retoričkih sredstava može se utvrditi kako je njihova učinkovitost utemeljena na suglasju više jezičnih razina, od fonološke do sintaktičke i da se upravo u njihovoj konstrukcijskoj simboličkoj strukturi, u smislu Langackera (1987), koja povezuje fonološku i značenjsku razinu može naći razlog njihovoj univerzalnosti i uporabnoj vrijednosti otpornoj na protok vremena.

Jedna od retoričkih figura koja se analizom političkog i javnog diskursa općenito pojavila kao vrlo uspješna u svojoj retoričkoj funkciji uvjeravanja jest i apofaza ili pretericija (Škarić 2008) jer u formi negacije sadržaja zapravo privlači pozornost slušatelja i stvara koncept koji se, na prvi pogled, želi negirati. Apofastičke se strukture najčešće rabe u svrhu difamacije ili neizravne pohvale osoba ili pojava i oslanjaju se na izazivanje zanimanja slušatelja stvaranjem određenih očekivanja na temelju naočigled negiranog sadržaja.

Korpusna analiza tipičnih apofastičkih konstrukcija u hrvatskom jeziku na primjerima iz političkog i medijskog diskursa u korpusu hrWaC pokazala je da se npr. zavisne objektne rečenice nakon glagola govorenja vrlo često rabe kao metoda uvođenja određenog pojma ili sadržaja koji se, površinski gledano, želi negirati suprotnim ili isključnim rečenicama. Tako se pretragom korpusa na slučajnom odabiru 100 rečenica s konstrukcijom Ne želim reći $d a$..., ali/nego/no... utvrdilo da je čak $26 \%$ primjera imalo tipičnu apofastičku funkciju uvođenja određenih tvrdnji zaobilaznim putem, tj. njihovom negacijom: Pritom ne želim reći da ona laže, nego samo to da imamo isključivo njezinu stranu priče. 
Polazeći od konstrukcijske naravi jezičnih izraza, u radu ćemo detaljno analizirati tipičnu sintaktičku strukturu apofastičkih konstrukcija s fokusom na pretericijske primjere i ulogu složenih rečenica u stvaranju željenih retoričkih i kognitivnih učinaka.

\section{Uvod}

Klasično shvaćanje retorike (Zarefsky 2005) proučava kako poruka utječe na ljude, tj. kako dolazi do razvoja i komunikacije znanja između govornika i slušatelja, pri čemu to tumačenje retorike u sučelju eksponencijalno uvećanih mogućnosti prijenosa informacija suvremenim vidovima komunikacije, kao što su elektronički mediji, internet i društvene mreže, upućuje i na povećanu odgovornost izgovorene riječi u istinitosti i djelotvornosti, u društvenoj korisnosti i opravdanosti, u toleranciji i etici, u estetici i govorno-jezičnoj pravilnosti te $u$ kulturi uopće.

Neka istraživanja političkog diskursa, poglavito onog parlamentarnog, upućuju na povećanje uvredljivih iskaza koji se oslanjaju na različite retoričke figure (Ilie 2001, 2004, 2010, Vančura i Tomić 2013). Te tendencije mogu upućivati ne samo na ozračje prisutno u kontekstu političkih sučeljavanja, već se putem medija $i$ sve prisutnijih komunikacijskih kanala različitih društvenih mreža prelijevaju i na ostale razine javne, pa i privatne komunikacije. Pri tome se razine izravnosti uvredljivih iskaza mogu očitovati i u samoj strukturi retoričkih figura, ali i u njihovu širem kontekstu kojim se iščitavaju i šire implikacije koje te figure mogu imati kako za slušatelja tako i za govornika. Često su te implikacije posljedica kognitivnog uobličavanja kojim jezične konstrukcije djeluju na konceptualni sustav kao integralni dio ljudskih komunikacijskih procesa, pa se može reći kako retorička sredstva počivaju na čvrsto ukotvljenim kognitivnim procesima kao što su, npr. već temeljito istražene konceptualna metafora i metonimija.

U središtu je naše pozornosti, međutim, retorička figura koja se tradicionalno naziva apofaza te u nekim svojim pojavnostima i pretericija ili prolepsa, a prema Škariću (2009) ubraja se u tzv. figure misli. Apofaza se sastoji od višestruko usložnjene rečenice koja svojom sintaktičkom strukturom najčešće prati glagole govorenja u glavnoj rečenici te objektne i suprotne rečenice u odnosu zavisnosti, tj. nezavisnosti: 
(1) Pritom ne želim reći da ona laže, nego samo to da imamo isključivo njezinu stranu priče.

Cilj je ovoga rada uputiti na mehanizme kojima ta retorička figura sintaktičkim sredstvima doprinosi uspostavljanju vrlo suptilnih manipulativnih učinaka kojima govornik utječe na svoju publiku, vrlo često uvodeći njome i uvredljiv sadržaj, a uspijevajući pri tome sačuvati obraz u njegovu pragmatičkom značenju. Pojmovnim uokvirivanjem koje sam sadržaj i njegovu kontekstualnu ukotvljenost usmjerava na točno određeni cilj, ta jezična figura pokazuje iznimnu retoričku snagu i opravdava svoju ulogu koja već stoljećima ne silazi s repertoara vještih govornika.

Nakon uvodnog dijela koji opisuje retoričku pozadinu te figure i njezine kognitivne mehanizme djelovanja, analizirat ćemo primjere najčešćih tipova konstrukcija s ciljem prepoznavanja njihove apofastičke naravi i funkcije u smislu retoričkih i pragmatičkih učinaka i uloge u uokvirivanju javnog diskursa s određenim manipulativnim namjerama. Nakon kraćeg osvrta na metodologiju istraživanja $\mathrm{u}$ analitičkom ćemo dijelu kvalitativnom i kvantitativnom analizom primjera ${ }^{1}$ u korpusu hrvatskog jezika hrWaC koji svojom sintaktičkom strukturom odgovaraju prototipnoj apofastičkoj konstrukciji utvrditi koliki su omjeri pojedinih tipova apofastičkih konstrukcija u odnosu na ukupan broj primjera slične sintaktičke strukture, dok ćemo u diskusiji opisati koja je uloga složenih rečeničnih sklopova u postizanju apofastičkih učinaka te na kraju iznijeti zaključke analize.

\section{Univerzalnost retoričkih figura}

\subsection{O retorici kroz prizmu kognitivne lingvistike}

Figurama se bave retorika, stilistika, lingvistika i poetika te one imaju iznimno interaktivan i multidisciplinaran karakter, a upravo on pridonosi i njihovoj univerzalnosti koja prelazi granice različitih jezika, te se može reći da retorički način izražavanja transcendira ograničenja različitih jezičnih sustava i predstavlja sustav za sebe, pri čemu se oslanja na univerzalne kognitivne obrasce koji

\footnotetext{
${ }^{1}$ Gdje nije drugačije naznačeno, svi su primjeri u radu iz korpusa hrWaC u izvornom obliku, kako su potvrđeni u korpusu: http://nlp.ffzg.hr/resources/corpora/hrwac/.
} 
se nalaze u pozadini svih jezičnih izraza, pa čak i u pozadini multimodalnih načina komunikacije. I iako Škarić (2000) tvrdi da gdje god se govori javno, govori se retorski i da pri tome vrijedi drugačije mjerilo nego za privatni govor, $\mathrm{u}$ analiziranim primjerima iz korpusa mogu se uočiti brojne konstrukcije koje svojom strukturom odgovaraju retoričkim apofastičkim konstrukcijama kojima se kontekst ne može naći u javnom govoru, nego proizlaze iz svakodnevne ljudske komunikacije. Sama njihova funkcija može varirati između one koju ćemo pripisati prototipnoj retoričkoj figuri, a to je manipulacija, tj. uokvirivanje pojmova s unaprijed određenom namjerom govornika/govornice. Uokvirivanje (engl. framing) je uporaba jezika koji odgovara nečijem pogledu na svijet (Lakoff 2004). Retorički govoreći, neki okvir promiče govornikovu preferiranu percepciju i stoga navodi pojedinca da upravo na taj preferirani način obrađuje zaprimljene informacije (Entman 1993). Iz toga proizlazi da govornik izlaže vlastitu inačicu istine i kanalizira pozornost publike na način da ona prihvaća upravo njegov ili njezin pogled na svijet. Ponavljanjem okvira kroz fiksne strukture, kao i već spomenutim zajedničkim pozadinskim znanjem, tj. kontekstom, usađenost koncepata u svijesti ljudi postaje sve veća, čime se otvara put njihovoj daljnjoj uporabi u širem krugu govornika.

Interaktivna priroda komunikacijskog procesa ogleda se u trenutnom diskurzivnom prostoru, kako ga naziva Langacker (2008: 59) i koji predstavlja „mentalni prostor koji se sastoji od svega što govornik i slušatelj imaju zajedničko i što predstavlja razgovornu osnovu u određenom trenutku" "2, što je vrlo važno za razumijevanje figura jer podrazumijeva zajedničko znanje i rituale u podlozi jezične komunikacije. Ono što Langacker (1987) naziva konstrukcijska simbolička struktura prepoznaje se i u nizu retoričkih sredstava koja povezuju njihovu fonološku i značenjsku razinu, pri čemu je njihova učinkovitost, utemeljena na suglasju više jezičnih razina, ta koja pridonosi univerzalnosti i uporabnoj vrijednosti retoričkih figura otpornih na protok vremena.

Važnost i relevantnost retoričkih figura prepoznata je u kognitivnoj lingvistici kroz proučavanje dvaju najčešćih kognitivnolingvističkih procesa, metafore i metonimije. Brojni su radovi koji konceptualnu pozadinu ljudske jezične komunikacije tumače upravo analizom metafora (Gibbs 2008, Lakoff 1993, 2004, La-

${ }^{2}$ „CDS is a mental space comprising everything presumed to be shared by the speaker and the listener as the basis for discourse at a given moment" (Langacker 2008:59). 
koff i Johnson 1980, Kövecses 2002, 2017, Steen 2011) i metonimija (Barcelona 2003, 2004, Littlemore 2015, Kövecses i Radden 1999, Panther i Radden 1999), kao i retoričkih figura kao što su hiperbola (Peña Cervel, Sandra i Ruiz de Mendoza 2017, Brdar-Szabó i Brdar 2010) ili ironija (Athanasiadou i Colston 2017). U suvremenim kognitivnolingvističkim pristupima te retoričke figure prestaju biti ono što se naziva „mrtvim” poetskim figurama i prepoznate su kao pokretači cijelog niza novih, kreativnih jezičnih izraza i temelji konceptualizacije.

\subsection{Apofastičke konstrukcije u taksonomiji retoričkih figura}

Postoji veliki broj figura koje se na različite načine klasificiraju. Iako se retoričke figure proučavaju još od antike (Aristotel, Ciceron, Kvintilijan itd.), u hrvatskom je jeziku njihova nomenklatura, nažalost, dosta neujednačena ${ }^{3}$ ili se često, pogotovo u posljednjih nekoliko godina, u nedostatku odgovarajućih termina, prevoditeljske „nespre $(\mathrm{t} / \mathrm{m})$ nosti” ili straha od mogućih nesporazuma zadržava uz postojeće nazivlje i nazivlje na engleskom/latinskom jeziku.

Aristotelova Retorika, koja se sastoji od triju knjiga, sadrži sustavnost kojom uključuje sva tri temeljna govornička elementa: Tko govori? Koji se argument iznosi? Kome se obraća? Polazeći od tih pitanja, Aristotel dolazi do spoznaje da kad izlažemo i pokušavamo uvjeriti dokazima, možemo to učiniti trima temeljnim elementima, $\mathrm{tj}$. na tri načina: kredibilitetom, ugledom, odnosno karakterom govornika (etos), dokazima koji se temelje na argumentima, analizi i koji proizlaze iz samog govora, načelom razuma (logos) te djelovanjem na emocije publike, raspoloženjem u koje se dovodi slušateljstvo (patos).

Škarić (2000: 109) definira retoričke (i/ili poetske) figure kao izraze kojima se nešto kaže na neobičan ili nedoslovan način, pri čemu svaka figura ima svoju svrhu, a figure se, prema Škariću (2000), dijele na: logičke figure, trope, figure misli, figure riječi, sintaktičke figure, morfološke, tvorbene i leksičke figure.

\footnotetext{
3 Tako Tošović (2007: 41) apofazijom, kao jednom vrstom kontradiktornog izraza, naziva jedino demantiranje ranijeg iskaza, ne i negaciju naknadnog sadržaja, Škiljan (1992: 74) spominje samo paralipsu (i latinizam praeteritio) kao način ,,izričitog naglašavanja da će iskaz o nekoj poznatoj pojavi biti izostavljen”, svrstavajući ju u figure diskursa koje nadilaze granicu rečenice i za koje je potrebno poznavanje šireg jezičnog konteksta, dok Bagić (2015: 262) apofazu i paralipsu ne spominje kao zasebne vrste ili nazive, već navodi pojam pretericije kao figuru misli kojom ,govornik najavljuje da neće govoriti o nekoj osobi, pojavi ili temi da bi odmah potom o istom iznio pojedine, nerijetko i sve, informacije kojima raspolaže".
} 
Tošović (2007), osim navedenih, razlikuje još i govorničke figure, stilističke/ /stilske figure, estetske figure, figure govora, figure jezika i gramatičke figure. Prema Škariću (2000: 130) pretericija/apofaza ubraja se u figure misli. Figure misli rečenice su u kojima misao, logički gledano, nije ono što te rečenice doslovno izriču, nego nešto drugo. Okolni i popratni znakovi uvijek jasno upućuju kako tu rečenicu treba shvatiti. To što se misli ne moraju izražavati uvijek na isti, predskaziv način govorniku ostavlja prostor za odabir, traženje, igru i stvaranje. Slušatelj dobiva od toga pojačan izraz - od iznenađenja, čuđenja do divljenja. Aristotel apofastičke figure spominje i u Kategorijama i u $O$ tumačenju, pri čemu ih opisuje kao podtip izjavnih rečenica u indikativu koje mogu biti potvrdne ili negirajuće (apophasis od apophanein 'poreći, reći ne'), pri čemu te apofastičke figure naizmjence potvrđuju i negiraju (De Int. 17-25), što i upućuje na njihovu ambivalentnu, manipulativnu narav o kojoj u ovome radu i govorimo. Kako ističe Tindale (2007), potreban je kontekst argumentacije koju svaki sposoban retor uspješno uvodi u svoj govor, a Richards (2008: 124) napominje kako je kontekst taj koji daje riječi značenje i samo kroz kontekst možemo otkriti značenje riječi.

Užim određenjem strukture apofastičkih konstrukcija može se prići iz različitih pozicija, pa se s obzirom na namjeru govornika određuju njihova pozitivna ili negativna afektivna svojstva, te tako imamo i zasebne figure koje u taksonomijama imaju i zasebnu kategoriju i ime.

Pretericija je tako u užem smislu retorička figura kojom se privlači pozornost slušatelja najavom da se o nečemu ne želi govoriti, ali se to što se tobože ne želi ispričati ispriča. Time se znatiželja slušatelja silno pojača i za ono što se „prešućuje" i za ono što slijedi; neki su od Aristotelovih primjera:

(2) Zašto da iznosim na vidjelo njegova naređenja, njegove otimačine, poklonjena i silom oteta nasljedstva.

(3) Nemam namjere iznositi svjedočanstva u vezi sa 600000 sestercija.

(4) Prijeći ću preko toga što je Filip, nekad tako malen, postao veliki i silan, kao i preko toga da Heleni među sobom nepovjerljivo i nesložno žive. Prijeći ću i preko toga, što je mnogo čudnije, što se Filip ni iz čega podigao, tolike zemlje poosvajao i još osvaja (prema Škarić 2000: 130). 
Litota je apofaza kojom hvalimo druge, ima pozitivnu svrhu za razliku od pretericije kojoj je svrha negativna:

(5) Skromnost kandidata sili me da izbjegavam govoriti o njegovim vrlinama, njegovom požrtvovanju, marljivosti, prijateljstvu (prema Škarić 2000: 128).

Ciceron u svom djelu Rhetorica ad Herrenium (1954: 321) spominje paralipsu koja „se javlja kad kažemo da ćemo nešto reći samo sporadično/letimično ili da nešto ne znamo ili odbijamo reći ono što upravo sada govorimo" i zapravo je, po retoričkoj svrsi, istovjetna apofazi ili pretericiji.

Ta je figura korisna ako ju želimo uporabiti u slučaju u kojem ne želimo izravno privući tuđu pozornost jer tom figurom možemo neizravno na nešto uputiti ili kada bi izravna referenca bila banalna ili nedostojna, nejasna ili takva da se može lako opovrgnuti. Uslijed toga veća je prednost stvoriti sumnju paralipsom nego izravno inzistirati na izjavi koja se može opovrgnuti:

(6) O tvojemu dječaštvu, doista, koje si posvetio nepodopštinama sviju vrsta, pričao bih kada bih mislio da je pravo vrijeme za to. Ali u ovome trenu ja ga mudro ostavljam po strani (Ciceron 1954: 321).

Tradicionalnim opisima apofaze u novijim se istraživanjima u hrvatskom javnom diskursu, primarno onom političkom, pridružuju i opisi njezine kontekstualno uvjetovane, funkcionalne uloge. Utvrđeno je, tako, da je primarna funkcija apofaze da se negirani sadržaj zapravo naglasi (Gradečak-Erdeljić i Gudurić 2017) ili sredstvo ublažavanja uvrede (Vančura i Tomić 2013). Naglašavanje ili ublažavanje pojedinih dijelova sadržaja ima manipulativni učinak jer se pozornost slušatelja preusmjerava s nepoželjnih činjenica ili se one pozitivne ističu uvodnom apofastičkom negacijom.

Pri tome se njezina legitimna uporaba ogleda u strategiji kada se govornik ograđuje od činjenica koje iznosi ili ih parafrazira nakon početne negacije:

(7) Time ne mislim reći da sad treba istraživati porijeklo i pedigre, sedam generacija unatrag, ali bi bilo normalno da gradonačelnik grada bude barem od ranog djetinjstva u tom gradu, da ga voli i da razumije kako grad diše i što mu treba.

(8) Nije nam nakana širiti nepotrebnu paniku, ali trenutne vrijednosti benzena u zraku u Slavonskom Brodu zabrinjavaju. 
Prema Brownu i Levinsonu (1987) ograde mogu imati bezbroj površinskih struktura, pa se tako višestruko složene rečenice u slučaju apofastičkih konstrukcija najčešće koriste u strategijama očuvanja obraza govornika, osobito u slučajevima negativne uljudnosti, što je ovdje svakako slučaj.

U drugoj krajnosti, u nelegitimnoj uporabi, radi se upravo o pretericiji, kada se do krajnosti nabrajaju negativne činjenice koje se, naoko, negiraju:

(9) Ne želim nikog napadati, ali mislim da je svima jasno kako situacija nije dobra, a u ovoj lakrdiji HDZ dalje ne može sudjelovati.

(10) Mogao bih reći da si dobar čovjek, ali isto tako mogu reći da si previše puta okolo sijao mržnju (koje je u tvojim napisima ipak daleko previše), častio ekipu svim mogućim epitetima i podjednako štetno djelovao na bilo kakvu mogućnost DIJALOGA između ljevice i desnice kao što to radi i Feniks.

Raznovrsnost pojavnosti apofastičkih konstrukcija koje se temelje na negaciji sadržaja u jednom dijelu rečenice, da bi se taj isti sadržaj u drugom dijelu rečenice naglasio, umnažao i elaborirao, bilo u njezinoj legitimnoj bilo u nelegitimnoj funkciji, temeljna je motivacija za proučavanje uloge višestruko usložnjenih rečenica kao sintaktičkih struktura koje imaju primarno retoričku, ali, kako ćemo pokazati, i kognitivnu pozadinu.

\subsection{Složene rečenice kao nositelji retoričkih figura}

Kako je već Aristotel (1954) uočio, u apofastičkim se konstrukcijama radi o indikativnim rečenicama koje negiraju u njima izrečeni sadržaj, pri čemu u glavnoj rečenici često imamo i glavni glagol, najčešće glagol govorenja ili mišljenja: reći, spomenuti, naglasiti, pomisliti u pogodbenom načinu, kojim se pojačava učinak ograđivanja kao jedne od primarnih funkcija tih konstrukcija. Negacija se može izreći i raznim perifrastičnim izrazima kao što su glagolsko-imeničke konstrukcije prijeći preko činjenice, ići u detalje i sl.

Temeljna se struktura tih konstrukcija, dakle, sastoji od glavne rečenice koju slijedi objektna surečenica kao nadopuna negiranom glagolu govorenja ili mišljenja: 
Ova prilično jednostavna struktura zavisnosložene rečenice izravno suprotstavlja izneseni sadržaj u objektnoj surečenici koji se, naizgled, negira u glavnoj rečenici. Češće se, međutim, u našem korpusu moglo naći primjere višestruko složenih rečenica u kojima se na osnovnu strukturu s objektnom surečenicom iz primjera (11) mogla naći i nadodana suprotna nezavisnosložena rečenica u kojoj se negirani sadržaj iz prvog dijela potvrđuje ili na neki drugi način apostrofira unutar druge objektne surečenice:

12)

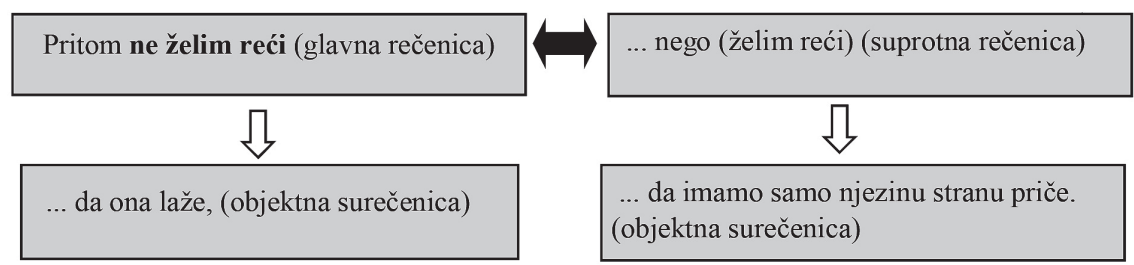

Višestruko složena rečenica u primjeru (12) prototipni je, pa i najučestaliji primjer apofastičke konstrukcije u našem skupu primjera, gdje se negacijski element nalazi u prvom dijelu, tj. u glavnoj rečenici, dok se afirmativni dio nalazi na prvoj razini zavisnosti, te negirani dio time biva stavljen u prvi plan. Tom se taktikom naglasak stavlja na sadržaj glavne rečenice na prvoj razini sintaktičkog uređenja, čime se govornik na samom početku iskaza ograđuje od informacije koja slijedi u zavisnoj rečenici, koja, međutim, ostaje iskazana i time usidrena u uhu i umu slušatelja, pa se tako i sadržaj koji se želi istaknuti stavlja u objektnu rečenicu, a pri govoru se upravo taj dio iskaza i naglašava. Sljedeći je korak u taktici ograđivanja apofastičkom konstrukcijom parafraza već rečenog, ali sadržajem i sintaktičkom strukturom suprotstavljena izrečenom u prvom dijelu rečenice, pa tako suprotna nezavisna rečenica (u ovom slučaju krnja, tj. bez istaknutoga glagolskog izraza želim reći) uvodi donekle ublaženi sadržaj iz mnogo izravnije i čak uvredljivije inačice prve objektne surečenice. Time je postignut ciljani učinak istovremene difamacije i ograđivanja od mogućih posljedica izravne objede koja se pod krinkom negiranja sadržaja dogodila u prvom dijelu iskaza.

Moguća je i struktura u kojoj se negirani element nalazi u drugom dijelu, u suprotnoj rečenici, pa se afirmativni dio nalazi u glavnoj i objektnoj rečenici: 
(13)

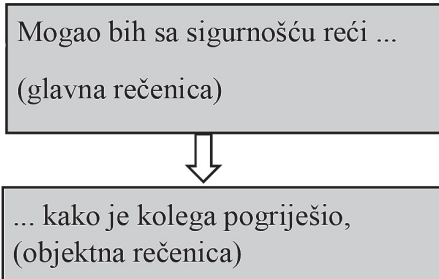

ali neću (reći) (suprotna rečenica).

Pri tome je negacija u suprotnim rečenicama vrlo često izrečena krnjim ili eliptičnim elementima koji se u govoru i naglašavaju, čime se postiže ironični odmak od afirmativnog dijela u prethodne dvije razine koje ipak donose glavninu željenog sadržaja.

Uloga je sintaktičke usložnjenosti u navedenim konstrukcijama upravo taktiziranje u iznošenju sadržaja, pri čemu naizgled istaknuti dio informacije koji nalazimo u objektnoj rečenici biva postupno zasjenjen kontrastnim sadržajem u suprotnoj rečenici, no potvrdni se sadržaj ipak zadržava u memoriji slušatelja i time glavna funkcija apofastičke konstrukcije biva ispunjena. Tošović (2007: 36) apofaziju, kako ju naziva, svrstava u trope kojima dominiraju sintagmatski, horizontalni odnosi kao determinante prostornih odnosa u smislu odrednice tip figure - tip korelacije. Time se zapravo sintaktička usložnjenost i poredak surečenica promatra kao funkcionalno relevantan element retoričkog učinka apofaze.

Zanimljivo je uočiti kako se među figurama misli, kako ih kategorizira Škarić (2000), nalazi još nekolicina sintaktički usložnjenih figura, npr. epifraza-dodatak, prividno sporedan, već izrečenoj misli, koja se time osporava, gdje imamo pogodbene zavisne rečenice:

(14) Demokracija je najgore društvo (ako isključimo sva ostala).

zatim koncesija koja izriče privremeno dopuštanje protivnikova stajališta:

(15) Priznajem da sam pogriješio, ali tko još nije počinio takvu grešku?

dok prolepsa (preduhitrenje) iznosi predviđanje mogućih prigovora i po svojoj je strukturi, koja uključuje i suprotne rečenice, vrlo slična apofazi:

(16) Znam da ćete reći kako govorim sa stajališta obrane, međutim ništa se drugo ni nema za reći.

Kako se može zaključiti iz primjera (11) - (16), složene rečenice imaju cilj u prvi plan staviti željeni sadržaj, što se postiže sintaktičkim usložnjavanjem u kojemu se 
igrom s razinama zavisnosti donosi željeni retorički učinak i postiže veće ili manje udaljavanje od središnje poruke, što govorniku omogućava i veću ili manju ogradu, tj. zaštitu od mogućih negativnih posljedica iznošenja određenog sadržaja.

\section{Metodologija istraživanja}

Na temelju građe prikupljene pri analizi američkoga političkog diskursa i predstavljene pri opisu studija slučaja uporabe apofastičkih konstrukcija u komunikaciji trenutnoga američkog predsjednika Donalda Trumpa (Gradečak-Erdeljić i Gudurić 2017), kao i pilot-istraživanjem hrvatskoga političkog diskursa u mrežnim izvorima, kao što su novinski mrežni portali, društvene mreže i sl. (Gradečak-Erdeljić i Gudurić 2016) inicijalno smo prikupili nekoliko stotina primjera koje smo analizirali na temelju strukture apofastičke konstrukcije koja se dijeli na dva temeljna tipa, i to prema položaju negiranog elementa u tvrdnji iskazanoj višestruko složenom rečenicom, gdje je u glavnoj rečenici prisutan glagol govorenja ili neka odgovarajuća perifrastična konstrukcija, u kojoj se nalazi objektna surečenica kojom se iznosi glavni sadržaj tvrdnje te suprotna rečenica uobičajeno nadopunjena još jednom objektnom surečenicom. Korpus hrvatskog jezika hrWaC poslužio je kao izvor za pretraživanje željenih konstrukcija tako da se tražene sintagme unijelo pod navodnicima u pretraživač kako bi ih se prepoznalo kao cjelinu. Analizirali su se oblici u kojima se negacijski element nalazi u prvom dijelu, 10 najčešćih iz pilot-istraživanja, kao i 2 najčešća s negacijskim elementom u drugom dijelu konstrukcije. Ukupno je prikupljen skup od 545 rečenica koje su sve tri suautorice nezavisno jedna o drugoj analizirale s ciljem utvrđivanja koje od rečenica imaju retoričku funkciju jezičnog uokvirivanja i manipuliranja sadržajem, tj. naoko negiranu tvrdnju zapravo potvrditi. Važno je napomenuti da se hrWaC pretraživao kao cjelina bez izdvajanja potkorpusa s obzirom na podvrstu diskursa, kao što bi bio medijski, politički ili privatni, upravo s ciljem da se uoči postoji li konstrukcijska stabilnost apofastičkih konstrukcija, tj. jesu li one prihvaćene kao široko primjenjive figure i prepoznaje li se njihov manipulativni učinak u smislu uokvirivanja sadržaja, kako je objašnjeno u 2.1. Kada se poklapanje u procjeni svih triju procjenjivačica nalazilo u rasponu od 80 do $90 \%$, prišlo se analizi preostalih, neusuglašenih primjera i, tek kada su se usuglasili svi slučajevi potencijalnih apofastičkih konstrukcija, prišlo se analizi 
učestalosti kojom se htjelo pokazati koji je omjer apofastičkih konstrukcija u ukupnom broju primjera, a s ciljem utvrđivanja njihove primarne retoričke funkcije, kao i njihova prepoznatljivog, konstrukcijskog statusa.

\section{Rezultati i rasprava}

U Tablici 1 navedeni su primjeri apofastičkih konstrukcija koje su prvotno elicitirane i koje su poslužile kao baza za pretragu u korpusu hrWaC. Može se uočiti kako su češće, ali i u svom konstrukcijskom statusu uočljivije konstrukcije s negacijom u prvom dijelu rečenice, gdje imamo negirani glagol govorenja ili mišljenja kao najčešću pojavnost, ali nisu rijetke ni perifrastične glagolsko-imeničke konstrukcije, većinom visokometaforizirani idiomatski izrazi, kao što su ići u detalje ili iznijeti na vidjelo. Nasuprot 11 primjera apofaze s negacijom u prvom dijelu nalazi se 6 primjera konstrukcija s negacijom u drugom dijelu višestruko složene rečenice, pri čemu je ona najčešće u obliku krnjeg predikata, gdje je izostavljen glavni glagol, a ostavljen je eliptični, pomoćni glagol ili neki drugi više ili manje idiomatizirani izraz, kao što je npr. daleko smo još od toga.

Tablica 1. Tipovi apofastičkih konstrukcija s obzirom na položaj negacije

\begin{tabular}{|l|l|}
\hline Negacija u prvom dijelu tvrdnje & Negacija u drugom dijelu tvrdnje \\
\hline Ne treba ni reći... & Mogao bih sa sigurnošću reći kako..., ali neću. \\
\hline Prijeći ću preko činjenice... & Moglo bi se govoriti o tome da..., ali nećemo. \\
\hline Ne moram ni spominjati... & $\begin{array}{l}\text { Sigurna sam da bismo imali dosta toga za } \\
\text { spomenuti, kao na primjer..., ali nećemo sada o } \\
\text { tome. }\end{array}$ \\
\hline Ne želim govoriti o tome... & Htio sam reći kako je sve to besmisleno, ali neću. \\
\hline Ne mislimo pritom sugerirati... & $\begin{array}{l}\text { Njegova je država jednostavno grozna, ali nisam } \\
\text { to ja tvrdio. }\end{array}$ \\
\hline Zašto iznositi na vidjelo... & $\begin{array}{l}\text { Komotno se može tvrditi da je naš položaj time } \\
\text { ugrožen, ali daleko smo još od toga. }\end{array}$ \\
\hline Ne treba vas podsjećati... & \\
\hline Bilo bi suvišno navoditi... & \\
\hline Nepotrebno je i pomišljati... & \multicolumn{2}{|c|}{$\mid$} \\
\hline Ne želim ići u detalje... &
\end{tabular}


Najučestaliji oblici apofastičkih konstrukcija u prikupljenom skupu primjera mogli bi se opisati sljedećim formulama: ,ne $+\mathrm{x}$, ali $\mathrm{x}(\approx \mathrm{x})$ ” ili ,x, ali ne x”, gdje se $\mathrm{x}$ odnosi na neki glagolski ili perifrastični oblik koji se u suprotnoj rečenici ili približno parafrazira ili se izravno negira ako se radi o drugom podtipu konstrukcija s negacijom u drugom dijelu rečenice:

(17) Mogao bih reći da mi je drago što ste pročitali komentar, ali neću lagati svejedno mi je.

(18) Nije mi nakana da sumnjam u bilo čije poštenje, međutim u ovom se slučaju očito radi o politikantstvu, predizbornoj kampanji i političkoj trgovini.

(19) Nije mi nakana posebice izdvojiti ovaj slučaj, ali mi je dao povoda, nakon svih posljednjih incidenata, nasilja, krađa, alkohola, druga, možda i prostitucije, postaviti pitanje jesmo li još uvijek miran, siguran i uredan Grad, kako se sa službenih razina podastire.

(20) Ne želim sugerirati da je Žarko Puhovski maliciozan i manipulativan, no i takav zaključak bi bio logičan.

(21) Bilo bi suvišno prebirati po biografijama svih sjajnih glumaca i tražiti tko je imao najuspješniju karijeru nakon Žice, ali kad bismo to radili čisto teoretski Idris Elba bi bio taj.

(22) Sada ne želim ići u detalje, no postoje brojni primjeri o tome što se uistinu može dogoditi na takvim, kako ih se može nazvati, zabavnim društvenim igrama.

Primjeri (17) - (22) reprezentativni su jer upućuju na funkciju suprotnih rečenica u tim višestruko složenim rečenicama, a to je istovremeno približavanje i udaljavanje od izrečene tvrdnje.

Pri analizi prikupljenih primjera osobita se pozornost posvetila razlikovanju neretoričke uporabe tih konstrukcija, tako da u obzir nisu uzimani primjeri u kojima se očito izražavao samo potvrdni sadržaj, bez implikacije da se radi o negativnom stavu prema izrečenom:

(23) Ne moram ni spominjati da što više mišića nosite, sagorijevate više kalorija pa čak i onda kada se odmarate.

(24) Ne sugeriram da svaki puta otvaramo usta jer, u stvarnosti, neke stvari jest bolje ne izreći. 
Svaki se pojedini primjer označio kao apofastičan ili ne, te su se u slučaju nepodudaranja u kategorizaciji suautorice konzultirale i dogovorio se konačan status svake rečenice ili konstrukcije. Moglo se uočiti da nije u svakom od primjera bilo riječi o javnom govoru koji bi, strogo uzevši, odgovarao njihovoj primarnoj retoričkoj funkciji, ali se u skladu s našom hipotezom o konstrukcijskoj naravi tih figura smatralo kako i privatni govor, npr. komentari s foruma ili blogova, ima istu namjeru kao i javno prezentirani, pogotovo ako se u obzir uzmu izvori primjera, a to su u slučaju korpusa hrWaC na internetu dostupne, više ili manje anonimne objave.

U Tablici 2 iskazani su omjeri pojedinih apofastičkih konstrukcija u odnosu na ukupan broj izdvojenih primjera u našem analiziranom skupu. Rezultati analize učestalosti upućuju na vrlo visoku prisutnost apofastičkih konstrukcija u svakom pojedinom pretraženom nizu.

Tablica 2. Učestalost apofastičkih konstrukcija u ukupnom broju izdvojenih primjera iz korpusa hrWaC

\begin{tabular}{|l|l|}
\hline Apofastička konstrukcija & hrWaC \\
\hline Mogao bih reći... (...ali neću.) & $30 \%$ \\
\hline Moglo bi se govoriti... & $41 \%$ \\
\hline Ne mislim reći... & $48 \%$ \\
\hline Ne moram ni spominjati... & $66 \%$ \\
\hline Ne želim sugerirati... & $79 \%$ \\
\hline Nije mi nakana... & $61 \%$ \\
\hline Ne treba vas podsjećati... & $50 \%$ \\
\hline Bilo bi suvišno... & $30 \%$ \\
\hline Ne želim ići u detalje... & $50 \%$ \\
\hline Nije mi ni na kraj pameti... & $43 \%$ \\
\hline Ne želim spominjati imena... & $46 \%$ \\
\hline Ne treba vas podsjećati... & $33 \%$ \\
\hline
\end{tabular}

Očito je iz ove analize učestalosti da su dva najčešća primjera apofastičkih konstrukcija negirani glagoli sugerirati i spominjati koji već po samom svom značenju upućuju na izvjesnu razinu neizravnosti, ograđivanja od naknadno izrečenog sadržaja, što odgovara naravi apofastičke konstrukcije. Nešto manja učestalost konstrukcija s Mogao bih reći ili Bilo bi suvišno... očita je posljedica 
visoke apsolutne učestalosti toga prvog primjera s čak 324 potvrde, dok u drugom slučaju imamo donekle formalni izraz koji i nije tako čest u govoru i pismu.

Sintaktička usložnjenost i negacija u ovim su primjerima čvrsto povezane, uzme li se u obzir asimetričnost negacije kako ih razumiju Hegel (1929) i Givon (1978), gdje su negirane propozicije manje relevantne od afirmativnih, $\mathrm{tj}$. ako ih se shvati kao afirmaciju drugog reda, kako to vidi Horn (2001). Pri tome se u negiranim izjavama zapravo radi o negiranim pozitivnim izjavama, dok same afirmativne izjave govore izravno o svijetu oko nas. Možemo uočiti i ono što Zovko Dinković (2013: 116) vidi kao opoziciju između deskriptivne i metalingvističke negacije, pri čemu je pragmatički učinak ograđivanja uzrokovan procesuiranjem višestruko složenih rečenica s višestrukom negacijom.

Ne može se ne uočiti i pragmatički učinak apofastičkih konstrukcija u okviru Griceove teorije konverzacijskih implikatura (1975), gdje se uz konvencionalno iščitavanje značenja apofastičkih rečenica uočava i kontekstualno uvjetovana negacija negacije, gdje slušatelj ili čitatelj vrlo često može pravilno uočiti da je komunikacijski obrazac apofaze zapravo tu kako bi naveo afirmaciju tvrdnje koja se, naoko, negira. U primjerima apofastičkih konstrukcija radi se o dvostrukoj motivaciji za njihovu uporabu jer mnogi govornici konstrukciju Ne želim tvrditi/sugerirati/reći... koriste kako bi očuvali jasnoću svoje argumentacije i uklonili sumnju o svojim stavovima te spriječili preuranjene zaključke publike, no pri tome je Griceova (1975) maksima relacije prekršena jer je relevantnost tvrdnje iznesene $u$ objektnoj rečenici umanjena negacijom u glavnoj rečenici. Mnogi govornici, međutim, „, ne misle reći” stvari koje publika sama nikada ne bi ni pomislila - sugestija je ipak dana, a obraz govornika sačuvan je. Pri tome možemo uočiti i ono što Tošović (1988: 160) naziva redundancijom pragmatičkoga funkcionalnog stila, prvenstveno pri tome misleći na kodnu redundanciju kao svjesno unošenje suvišnih elemenata u jezičnu poruku, a pragmatička teorija informacije (Tošović 1988:152) ljudski čimbenik diže na razinu središnjeg čimbenika u procesu prenošenja informacije jer on upravlja neskladom između kodirane i dekodirane informacije, izazivajući time manjak entropije kao posljedice sukoba redundancije jezičnog izraza i jezične ekonomije.

Na djelu je u ovim slučajevima proces uokvirivanja, postupka jezičnog uobličavanja misli na način da se manipulira jezičnim sadržajem kojim se te misli izražavaju. Uokvirivanje je kao proces osobito prisutno u političkom diskursu, 
gdje se prezentiranje političkih ideja vrši tako da se potiče jedna interpretacija nauštrb druge (Feldman 2007). Apofastičke konstrukcije temelje se na promoviranju naoko negiranih ideja, a kako je još prije ustvrdio Lakoff $(2004,2008)$, izbore ne dobivaju činjenice, već emocije, tako da se negiranjem činjenica koje se ipak putem tih konstrukcija izlažu dolazi do određenog emocionalnog stanja neodlučnosti i nesigurnosti, pa je slušatelj podložniji suptilnim sugestijama vještog govornika. Pri tome, kako elaborira Lakoff (2008), racionalno razmišljanje ne pomaže, već duboko usađene mentalne slike koje se potiču ključnim riječima, metaforama i strateškim frazama.

\section{Zaključci}

Višestruko složene rečenice u korpusu apofastičkih konstrukcija na tragu su konstrukcijskih, duboko usađenih oblika koji se iz korpusa javnog govora prelijevaju i u privatni govor, tako da iz našeg skupa elicitiranih struktura svojom učestalosti upućuju na širu uporabu tih retoričkih figura. Raznovrsnost pojavnosti apofastičkih konstrukcija, koje se temelje na negaciji sadržaja u jednom dijelu rečenice da bi se taj isti sadržaj $u$ drugom dijelu rečenice na različite načine parafrazirao, temeljna je motivacija za proučavanje uloge višestruko usložnjenih rečenica kao sintaktičkih struktura koje imaju primarno retoričku, ali i kognitivnu pozadinu jezičnog uokvirivanja komuniciranih sadržaja. Manipulativni učinak apofaze kao jezičnog sredstva ogleda se u namjernom sintaktičkom usložnjavanju koje je često redundantno u smislu da se obično u početnoj, glavnoj rečenici uvodi negacija sadržaja koji se izlaže u objektnoj surečenici. Analizirani primjeri ukazuju na ustaljeni konstrukcijski obrazac kojim se uvodno negira često i uvredljivi sadržaj iskazan u objektnoj rečenici, što ne sprječava da se sadržaj i iznese, čime je postignut cilj, a to je da se uvreda ili bilo koji drugi negativno intonirani sadržaj i iznese.

Leksički i sintaktički negirani elementi doprinose otežanom procesuiranju sadržaja pri čemu je ugrožena ikonička struktura prototipnih složenih rečenica koja uspostavlja jasno odvojene razine prvog i drugog plana informativnosti sadržaja, a paralelni postupci iznošenja negiranog i potvrđenog sadržaja uvode osjećaj pojmovne nesigurnosti koji može biti podloga za manipulaciju od strane govornika. 
Retoričke figure, između ostalog, duguju svoju uporabnu i univerzalnu vrijednost i dobro navođenoj sintaktičkoj organizaciji jezičnih konstrukcija, pa apofastičke konstrukcije u svojoj kreativnoj primjeni mogu biti primjer kako se tradicionalno poimane figure misli zapravo mogu reinterpretirati kao sučelje $u$ kojemu se na simboličkoj razini susreću sintaktičke i konceptualne vrijednosti jezičnih izraza.

\section{Literatura:}

Aristotel. 1954. Kategorije. Kultura. Beograd.

Aristotel. 1989. O tumačenju. Latina et Graeca. Zagreb.

Aristotel. 1989. Retorika. Naprijed. Zagreb.

Athanasiadou, Angeliki; Colston, Herbert L. (ur.). 2017. Irony in Language Use and Communication. John Benjamins. Amsterdam.

BAGIĆ, KREŠIMIR. 2015. Rječnik stilskih figura. Školska knjiga. Zagreb.

Barcelona, Antonio. 2003. Claryfying and Applying the Notions of Metaphor and Metonymy within Cognitive Linguistics: An Update. Metaphor and Metonymy in Comparison and Contrast. Ur. Dirven, René; Pöring, Ralf. Mouton de Gruyter. Berlin. 207-277.

Barcelona, Antonio. 2004. Metonymy behind grammar: The motivation of the seemingly 'irregular' grammatical behavior of English paragon names. Studies in Linguistic Motivation. (Cognitive Linguistics Research 28). Ur. Radden, Günter; Panther, Klaus-Uwe. Mouton de Gruyter. Berlin - New York. 357-374.

Barcelona, Antonio (ur.). 2015. Metaphor and Metonymy at the Crossroads. Mouton de Gruyter. Berlin - New York.

Brdar-Szabó, Rita; Brdar, Mario. 2010. "Mummy, Ilove you like a thousand ladybirds": Reflections on the emergence of hyperbolic effects and the truth of hyperboles. Tropical Truth(s): The Epistemology of Metaphor and Other Tropes. Ur. Burkhardt, Annette; Nerlich, Brigitte. Mouton de Gruyter. Berlin - New York. 383-427.

Brown, Penelope; Levinson, Stephen C. 1987. Politeness: Some universals in language use. Cambridge University Press. Cambridge.

Ciceron. 1954. Rhetorica ad herennium with an English translation by Harry Caplan. William Heinemann Ltd/ Cambridge. Massachusetts Harvard University Press. London.

Entman, M. Robert.1993. Framing: Toward Clarification of a Fractured Paradigm. Journal of Communication 43. 51-58.

GibBs, Raymond W. JR. (ur.). 2008. The Cambridge Handbook of Metaphor and Thought. Cambridge University Press. Cambridge. 
Givón, Talmy. 1978. Negation in Language: Pragmatics, Function, Ontology. Pragmatics. Ur. Cole, Peter. Academic Press. New York. 69-112.

Gradečak-Erdeljić, Tanja; Gudurić, Dorijan. 2016. It goes without saying...(though I will say it anyway). Izlaganje održano na međunarodnom znanstvenom skupu ESSE 2016. Galway, 22. - 26. 8. 2016.

Grice, Herbert Paul. 1975. Logic and Conversation. Syntax and Semantics. Vol. 3. Ur. Cole, Peter; Morgan, Jerry. Academic Press. New York. 22-40.

Hegel, Georg Wilhelm Friedrich. 1929. Science of Logic. Vol. 1. George Allen and Unwin LTD - The Macmillian Company. London - New York.

Horn, Lawrence R. 2001. A natural history of negation. The David Hume Series. Philosophy and Cognitive Science Reissues.

Ilie, Cornelia. 2001. Unparliamentary Language: Insults as Cognitive Forms of Ideological Confrontation. Language and Ideology Volume ii: Descriptive Cognitive Approaches. Ur. Dirven, Rene; Frank, Roslyn; Ilie, Cornelia. John Benjamins Publishing Company. Amsterdam -Philadelphia. 235-262.

Ilie, CoRnelia. 2004. Insulting as (un)parliamentary practice in the British and Swedish parliaments: A rhetorical approach. Cross-Cultural Perspectives on Parliamentary Discourse. Ur. Bayley, Paul. John Benjamins Publishing Company. Amsterdam - Philadelphia. 45-86.

Ilie, Cornelia. 2010. Analytical perspectives on parliamentary and extra parliamentary discourses. Journal of Pragmatics 42/4. 879-888.

Köveces, Zoltán; Radden, Günter.1999. Towards a Theory of Metonymy. Metonymy in Language and Thought. Ur. Panther, Klaus-Uwe; Radden, Günter. John Benjamins. Amsterdam. 17-60.

Kövecses, Zoltán. 2002. Metaphor. A Practical Introduction. Oxford University Press. Oxford - New York.

Kövecses, Zoltán. 2017. Levels of Metaphor. Cognitive Linguistics 28/2. 321-347.

Lakoff, George 1993. The Contemporary Theory of Metaphor. Metaphor and Thought. Ur. Ortony, Andrew. Cambridge University Press. Cambridge. 202-251.

Lakoff, George. 2004. Don't think of an elephant. Chelsea Green Publishing. White River Junction.

LAKOFF, GeORGE. 2008. The political mind. Why you can't understand $21^{\text {st }}$-century politics with an $18^{\text {th }}$-century brain. Viking. New York.

Langacker, Ronald W. 1987. Foundations of Cognitive Grammar. Vol 2: Descriptive Application. Stanford University Press. Stanford.

Lakoff, George, Mark Johnson. 1980. Metaphors We Live by. The University of Chicago Press. London - Chicago.

Littlemore, Jeannette. 2015. Metonymy. Cambridge University Press. Cambridge. 
Langacker, Ronald W. 2008. Cognitive Grammar: A basic introduction. Cambridge University Press. Cambridge.

Panther, Klaus-Uwe; Radden, Günter (ur.). 1999. Metonymy in Language and Thought. John Benjamins. Amsterdam.

Peña Cervel, Sandra; Ruiz de Mendoza, Francisco. 2017. Construing and constructing hyperbole: Cognitive Foundations of Language Structure and Use. Studies in Figurative Thought and Language. Ur. Athanasiadou, Angeliki. John Benjamins. Amsterdam. 42-73.

Steen, Gerard 2011. The Contemporary Theory of Metaphor - Now New and Improved! Review of Cognitive Linguistics 9. 26-64.

Tindale, Christopher W. 2007. Fallacies and Argument Appraisal. Cambridge University Press. Cambridge.

ToŠOvić, BRANKO. 2007. Figura kao korelacija. Razgovori o retorici. Ur. Ivas, Ivan; Škarić, Ivo. Hrvatsko filološko društvo - Filozofski fakultet Sveučilišta u Zagrebu - Odsjek za fonetiku. Zagreb. 35-48.

ŠKARIĆ, Ivo. 2000. Temeljci suvremenog govorništva. Školska knjiga. Zagreb.

ŠKiljan, Dubravko. 1992. Dijalog s antikom. Eseji iz antičke lingvistike. Latina et Graeca. Zagreb.

Vančura, Alma; Tomić, Diana. 2013. The Analysis of Insulting Practices - Sticks and Stones in the Croatian Parliament. What do we know about the world? Rhetorical amd argumentative perspectives. Ur. Kišiček, Gabrijela; Žagar, Igor Ž. Windsor Studies in Argumentation, University of Windsor. Open Monograph Press. 143-158.

ZAREFSKy, DAVID. 2005. Argumentation, the study of effective reasoning. The Teaching Company. Chantilly, VA.

\section{Apophastic Constructions in Croatian at the Intersection between Rhetoric and Syntax}

Abstract

By analysing various rhetorical figures, it may be established that their efficiency is based on the interaction of several linguistic levels, from the phonological to the syntactic one. Precisely their symbolic constructional structure, as proposed by Langacker (1987), which connects the phonological and semantic poles may be the reason for their universality and usage value resistant the passage of time.

In our analysis of political and public discourse in general one of the rhetorical figures showed as particularly successful in its rhetorical function of persuasion is apophasis or praeteritio (Šakrić 2008). It has a form of negating the content of the utterance while 
it actually attracts the attention of the listener by creating the concept which is, at the first glance, to be negated. Apophastic structures are most frequently used with the purpose of defamation or indirect praise of individuals or phenomena and relies on raising the interest of listeners by creating specific expectations on the basis of the obviously negated content.

Corpus analysis of typical apophastic constructions in Croatian in examples from political and media discourse in the hrWaC corpus showed that e.g. dependent object clauses after verbs of speaking frequently serve as a method of introducing a specific concept or content, which is, superficially viewed, to be negated by a following contrast or exclusive clause. Our corpus search on a randomly chosen hundred sentences containing the construction "Ne želim reći da..., ali/nego/no..." ('I don’t want to say that..., but/still/however...') established that even $26 \%$ of examples had a typical apophastic function of introducing specific claims in a roundabout way, i.e. by negating them:

Pritom ne želim reći da ona laže, nego samo to da imamo isključivo njezinu stranu priče. By this I don't want to say that she's lying, but that we have only her side of the story.

Adopting the constructional nature of linguistic expressions, we shall analyse in more detail a typical syntactic structure of apophastic constructions with the focus on praeteritio examples and the role of complex sentences in creating the desired rhetorical and cognitive effects.

Keywords: rhetoric, syntax, apophasis, multiple sentences, cognitive linguistic, framing Ključne riječi: retorika, sintaksa, višestruko složene rečenice, kogntivna lingvistika, uokvirivanje 